\title{
Against All Odds: The History of Archaeological Research in Somaliland and Somalia
}

\author{
Jorge de Torres Rodríguez, Spanish National Research Council (CSIC)
}

\begin{abstract}
This article presents an overview of the history of archaeological work in Somaliland and Somalia from the late nineteenth century to the present, situating that work within its ever-changing social and political contexts. It also assesses the current challenges and opportunities that archaeological practice faces in both regions. Despite numerous obstacles - including political instability, a fragmented academic community, and deficiencies in the publication and dissemination of findings in multiple research languages - the article contends that the extensive data from previous and current archaeological studies, if assembled and properly utilized, can shed light on a range of key questions in the prehistory and history of the Horn of Africa. Finally, the article notes the growing threats to the archaeological and historical heritage in the region, and suggests how institutions, academics and the Somali community can join efforts to protect and preserve the remains of one of the most impressive African heritages.
\end{abstract}

Northeast African Studies, Vol. 18, Nos. 1-2, 2018, pp. 265-??. ISSN 0740-9133. @ 2019 Michigan State University. All rights reserved. 
Jorge de Torres Rodríguez

\section{Introduction}

There is little doubt that the Horn of Africa is one of the most dynamic regions in Africa, a crossroads connecting a complex tapestry where cultures, religions, ethnicities, and languages are interwoven and where the material expressions of these connections constitute one of the most important legacies of world heritage. However, the study of these material expressions has had mixed fortunes. Although in Ethiopia archaeology was consolidated as a discipline in the 1920s and remains one of the most active tools in the study of the history of the Horn of Africa, and although research on the material past has been relatively constant in Djibouti and Eritrea, the development of archaeology in Somalia has been intermittent at best, and fragmented to the point that it is difficult to speak of a Somali archaeology at all. Although neighboring areas such as the Arabian Peninsula, the Ethiopian highlands, or the Swahili coast have long-established archaeological traditions that include permanent institutions, thematic conferences, research groups, and active academic communities, the archaeology of Somalia has always oscillated between a widespread recognition of its importance and a notable lack of continuity of mission, direction, and funding.

Recent discontinuities in the archaeological enterprise can be explained in part by the political situation in Somalia and the neighboring regions, especially after the collapse of the Somali state in 1991. Of course, political instability and violence discourage the development of research strategies and severely limit the most important form of archaeological investigation: fieldwork. However, from our perspective there are other factors that hindered the consolidation of Somali archaeology over the course of the twentieth century. Perhaps the most relevant is the impact of the distribution of the Somali people into five different countries following the colonial partition of Africa at the end of the nineteenth century. These five territories have seen the development of independent research traditions rooted in markedly different colonial occupations, using distinctively different research strategies and with information published in three main languages (Italian, English, and French) along with a few others such as Russian or German. This fragmentation has made it difficult to conduct cross-border fieldwork and has limited the collaboration and integration of data throughout the region. 
Moreover, the weight of research traditions and political agendas has acted as a centrifugal force and made Somali archaeology the weakest link in the study of the Horn's material past. Even in Ethiopia, the heavy emphasis on the material remains of the highland Christian tradition has, until recently, left the southern and western borderlands along with the Muslim parts of the country largely unattended.

When one adds the lack of public resources in the countries of the region to these multiple political, geographical, scientific, and linguistic discontinuities, it is easy to understand why Somali archaeology over the years has not developed a coherent research agenda or found synergies with the scholarship of its neighbors. The outcome of this inconsistency is a mosaic of different methodological and theoretical approaches, short-lived projects, and isolated initiatives that have never been analyzed as a whole and that, in the end, have failed to provide a comprehensive picture of archaeology's possibilities for helping us reconstruct the material past of Somalia and the Somalis.

This article aims to amend the vision of Somali archaeology as a nonexistent or incoherent discipline by 1) summarizing the poorly known history of archaeological research in Somalia and Somaliland, and 2) highlighting a selection of the key themes present in the literature since research began in the region. By organizing and presenting a substantial corpus of information that is often difficult to access and even harder to synthesize, this article hopes to fill a gap in the historiography of the region and set out some elements for discussion about the future of Somali archaeology. The article will focus on the research conducted in Somalia and Somaliland, which are the two least studied territories of the Somali-inhabited lands, although it will also include references to Djibouti, Kenya, or Ethiopia where appropriate.

\section{The History of Archaeology in Somalia and Somaliland}

The Early Years (Nineteenth Century to Independence)

The first Western mention of archaeological remains in Somalia can be credited to Richard Burton (1894) who noticed towns in ruins during his trip 
from Zeila to Harar in 1854. However, the first scientific references to material remains come from later nineteenth-century visitors such as Georges Revoil, who travelled extensively along the Somali coast and through the Darror Valley (Revoil 1882) where he documented for the first time the characteristic cairns scattered throughout the region. The materials gathered by Revoil along the Somali coast included lithic tools (Clark 1954, 16) and pieces from China, India, and Yemen (Pradines 1999), and, more interesting, a set of Roman and Egyptian glasses and pottery recovered in Heis in northern Somalia (Desanges 1992, Desanges, Stern, and Ballet 1993) dating from the first century C.E. (Desanges, Stern, and Ballet 1993, 22), which may provide evidence of trade in the region during antiquity. After Revoil's trip, the increasing presence of Europeans on Somalia's coasts led to a growing interest in the archaeology of the region, especially regarding Stone Age artifacts. In Italian Somaliland, the Robecchi-Briccheti Expedition (1891) and the du Bourg de Bozas Expedition (1901) gathered stone tools in the districts of Obbia and Webi Shebeli, respectively (Clark 1954, 16). In British Somaliland, MacConkey (Josseaume 1895), Count Wickenburg (Paulitschke 1898), and especially Seton-Karr from 1897 onwards (Evans 1896-1987; Seton-Karr 1896) recovered the first significant samples of lithic tools that would provide the foundations for Late Stone Age (LSA) studies in the region (Clark 1954, 22-23).

The incipient interest of outsiders in Somali prehistory would, however, stall during the first two decades of the twentieth century due to the rebellion of Sayyid Muhammad 'Abdille Hassan, which severely disrupted British Somaliland and prevented further research in the region. The twenty-year conflict also affected Italian Somaliland, where only one expedition was conducted, in 1913 (Graziosi 1938, 930). The defeat of the Somali dervishes in 1920 and the increasing control of the colonial authorities over the two territories (Lewis 2002, 98-99) would create the conditions for the first period of proper archaeological research in Somalia, lasting from the mid1920s to the beginning of the Second World War. The research was enhanced by the activity of the Anglo-Italian (1929-30) and the British-Ethiopian (1932-34) commissions to demarcate the borders between the two colonies and Ethiopia (Lewis 2002, 106). The presence of numerous scholars in the different delegations gave a significant boost to the knowledge of Somali archaeology, which starts then to be properly studied. 


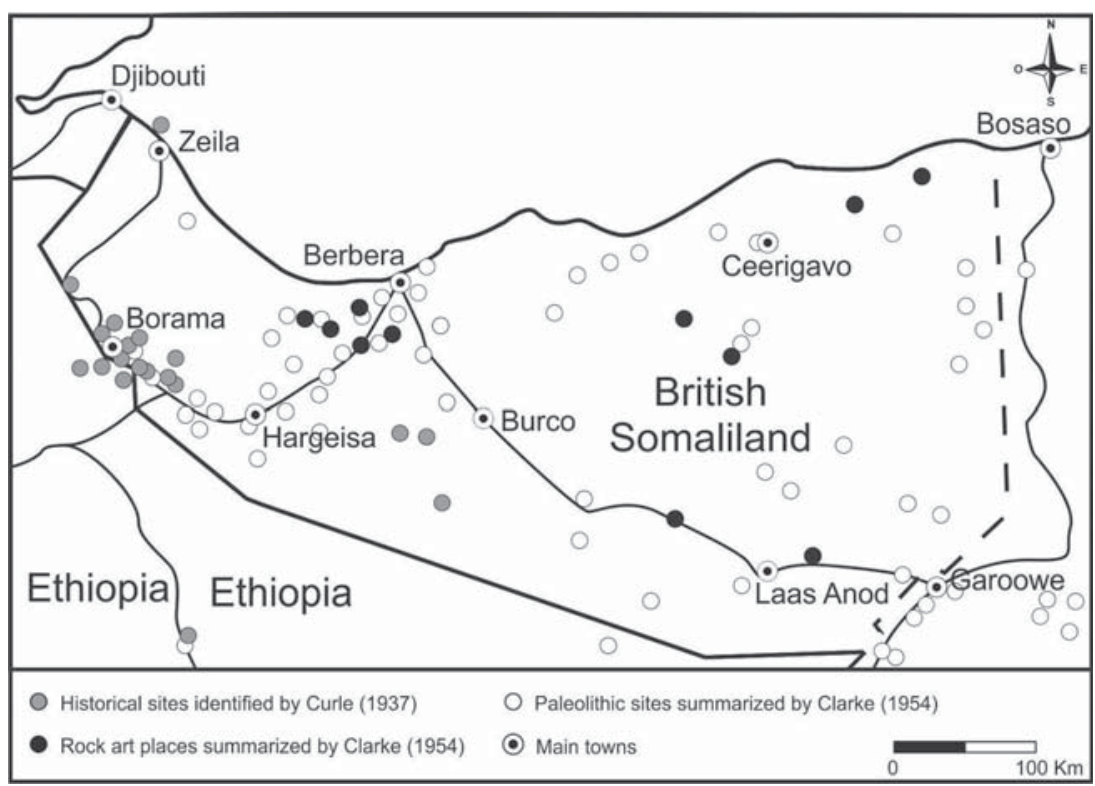

FIGURE 1. Archaeological sites identified in British Somaliland during the colonial period.

In Italian Somaliland, expeditions were conducted in 1924 and especially in 1935, excavating for the first time several caves and rock shelters with LSA and Neolithic materials (Graziosi 1940). The noted orientalist Enrico Cerulli (1931) also published brief notes about funerary monuments in the Midjurtina. Around the same time, Barrington Brown assembled a collection of artifacts from the northeastern British Somaliland Protectorate (Clark 1954, 23). But it was A. T. Curle - a member of the British-Ethiopian Boundary commission - who was most active, surveying a number of ruined towns in the western British Somaliland Protectorate, most of them around the town of Borama (Curle 1937a). Curle's study of these towns - which he dated in the period of the Adal sultanate (fifteenth-sixteenth centuries) - and of other structures (Curle 1932; 1937b) in the area was pioneering: it combined excavations with the use of aerial photography and the use of historical texts to contextualize the sites, and included thorough documentation of the imported materials found in them. Combined with a short report by G. W. B. Huntingford (1978), they constitute the first approach to the historical archaeology of Somalia in a moment when Stone Age studies were dominant. 
After World War II, the British and Italian territories were briefly unified under British military administration. The defeat of Italy had curtailed research in Somalia, and only after the establishment of the Italian Trusteeship Administration (AFIS) in 1950 was a new research project launched in 1953, directed by the Italian specialist on the region, Paolo Graziosi (1954). British archaeology in Somalia, on the other hand, had a major boost thanks to the work of J. D. Clark, who while in service in Somalia conducted several field trips in the country between 1941 and 1946. The result of his work, which combined his excavations and surveys with the study of the previous collections, constitutes the only synthesis of the earlier stages of the prehistory of the Horn of Africa (Clark 1954). Clark's book also includes a chapter on rock art, which had been documented for the first time in the 1940s (Burkitt and Glover 1946) and has become since then a recurrent topic of study in Somali archaeology.

\section{Archaeology in Independent Somalia}

Unfortunately, the benchmark represented by Clark's book and the renewal of Italian interest in Somalia's archaeology during the early AFIS period (Graziosi 1954) were not followed up in the later 1950s, which culminated with the end of the British Protectorate on June 26 and Somalia's independence on July 1, 1960. Apart from brief publications of excavations conducted in the previous decade (Lewis 1961) or studies of coin hoards from sites along the Somali coast (Freeman-Grenville 1963), the first independence decade saw little archaeological activity in Somalia. The only significant new initiative was the expedition conducted in 1968 in southern Somalia by Neville Chittick, at that time director of the British Institute of East Africa (BIEA). Chittick visited a number of places between Mogadishu and the Kenyan border, and published the first academic article on the relevant historical remains of the Benadir (southern Somali) coastal region (Chittick 1969), which had some links to the Swahili cultural zone further south.

Even this limited work did not have a proper follow-up due to the assassination of Somalia's president, Abdirashid Ali Shermarke, and the military coup d'état on October 21, 1969, which dramatically ended the 
country's archaeological collaboration with the BIEA. However, increasing support from the Soviet Union for Siad Barre's military regime had its own impact on archaeology: a joint Soviet-Somali Scientific Expedition undertook missions in 1971 and 1973 in northern Somalia (Solodovnikov 1974, 7). The archaeological project, directed by S. A. Warsame, A. Nikiforov, and L. L. Galkin, visited Amud, Gorbag, and Abassa in the Borama area (Warsame, Nikiforov, and Galkin 1974, 320-3), Zeila on the western coast (323-26), and the rock art site of God-Hardune (316), close to El Afweyn, and documented several cairn areas in northern Somalia. Although the final report of the expedition is detailed and reflects an interest in topics such as precolonial international trade (327-28), the initiative did not lead to further Soviet-sponsored research. Instead, it was Neville Chittick who was invited by the Somali government in 1975 to resume his work in the country (Chittick 1976).

Chittick conducted two fieldwork campaigns in Somalia (1975 and 1976). The first one focused on the area north of Mogadishu (the southern part having been visited in 1968), and for the first time it had a clearly defined objective: to document possible pre-Islamic coastal sites (Chittick 1976, 119). The survey was extremely successful, locating several places whose chronology could be established for Antiquity. Probably the most important site was that of Ras Hafun, a peninsula on the northeast coast of Somalia and connected to the continent by a twenty-kilometer arm of sand where Chittick excavated two sites. The first one (Hafun Main) is located to the southwest of the peninsula and consisted of two rectangular stone structures, with a scattering of materials to the south, including some of possible Parthian and Roman origin (Chittick 1974, 121). A second site (Hafun West) was located to the northwest, and consisted of a group of pillars and slabs and the remains of a possible rectangular building. In this area, a shard of Ptolemaic or Egyptian pottery was found, along with a glass bead and a copper rivet-like piece (Chittick 1974, 122). Although Ras Hafun was the most important site discovered during this season, evidence of ancient trade was also found in Damo (Chittick 1976, 124), and a series of important places were identified for the first time, including the deserted town of Maduna, close to El Afweyn, the only evidence of an eastern town similar to those of Borama close to the border with Ethiopia. 
The importance of Chittick's findings and the material confirmation of the trade stations described by the Peryplus of the Erythrean Sea (first century C.E.) led to a second fieldwork campaign in Ras Hafun in 1976 in collaboration with Mathew C. Smith. The two sites initially located by Chittick were excavated and a thorough study of their material remains was undertaken during the following years, while the first studies on the identification of archaeological sites with Classical texts were published (Chittick 1979) and presented at the Eighth Congress of Panafrican Studies in 1977 (Chittick 1980). Unfortunately, the deaths of Chittick and Mathew Smith prevented the publication of a final monograph of the Ras Hafun excavations. Only in the late 1980s were some of the materials and illustrations published by Wright (Smith and Wright 1988; 1990). Much of the other information gathered by Chittick and Smith remains at the BIEA in Nairobi, whereas the materials stored in Mogadishu are certainly lost.

We do not know exactly why the Ras Hafun excavations were suspended, although the 1977 Ogaden War and its disruptive aftermath probably played a role. Following this conflict, the Siad Barre regime severed its links with the Soviet Union (Lewis 2002, 235-36), and sought to renew friendly ties with Western countries. This shift would prove to be a boon to archaeological research. The 1980s saw many activities in Somalia, with the launching of several new long-term projects and the first attempts to recruit Somali personnel for training as archaeologists. One symbol of this awakening was the celebration of the first Congress of the Somali Studies International Association (SSIA) in Mogadishu in July1980, when a number of papers on Somali archaeology were presented. Along with a paper of Chittick about cairns in northern Somalia (1992), two studies on the coastal ruins of southern Somalia were delivered (Allen 1992; Wilson 1992), along with an introduction to Somali prehistory by Steven Brandt (1992), who had started a project that same year (1980) in northern Somalia. For the occasion of the Congress, Chittick excavated two trenches in Mogadishu in the vicinity of the Jami' Mosque (Chittick 1982). Reaching a depth of six meters (60), the excavations were inconclusive for demonstrating the existence of Mogadishu before the twelfth century, challenging prior assumptions of an earlier ninth-century foundation for the city (61).

The boost to Somali archaeology in the 1980s consisted of three major 
initiatives. The first one centered on the activity of Steve Brandt, who between 1980 and 1989 oversaw the longest continuous period of archaeological research in Somalia, mostly focused on prehistoric sites. A second research initiative was launched by the Italian scholar Margherita Mussi, who worked intermittently in southern Somalia, again with prehistoric sites. Finally, growing concerns about the preservation of the Somali heritage and the lack of local experts on archaeology led to concerted efforts by UNESCO and the Swedish Agency for Research Cooperation (SAREC) to implement training programs for Somalis in both archaeology and museum-heritage management. Along with other small surveys undertaken by Hilary C. Sanseverino (1983; 1988) and Wilson (1992) near the border with Kenya, these initiatives appeared to set the foundations for the sustained growth of Somali archaeology. The stability of midterm projects, the integration of teams of researchers, the training of local personnel, the concern about economic development's impact on heritage sites, and the attempts to provide better facilities for the storage and display of materials collectively signaled a promising departure from previous periods of lackluster archaeological activity. Although still modest, the advances seen in the 1980s represented a significant step towards the integration of Somali archaeology into the wider contexts of research on African prehistory and history.

At the core of this revival was Steven A. Brandt, who started his work in Somalia in 1980 and pursued it until 1989 through three main projects. The first one (1980-82) was based in northern Somalia and combined a return to the sites described by Clark or Seton Karr with surveys in the area between Las Khoreh and Erigavo (Brandt, Brook, and Gresham 1984, 8). During the fieldwork campaign of 1982 three sites were excavated (Medishe, Gud, and Karin Hegaan), providing the first systematic series of radiocarbon dates in the country (Brandt et al. 1984, 15-16; Brandt and Brook 1984, 10). In addition, the important rock art paintings of Karin Hegaan published by Clark (1954, 303) were also thoroughly documented. Similar to those of Las Geel, these paintings were linked to the so-called "Ethiopian-Arabian" style (Brandt and Carder 1987, 198) and were integrated into the discussion about the introduction of humped cattle in the region (Carder 1987).

Although both the rock art and the results of several test pits looked promising for further investigation, in 1983 Brandt launched a new project, 


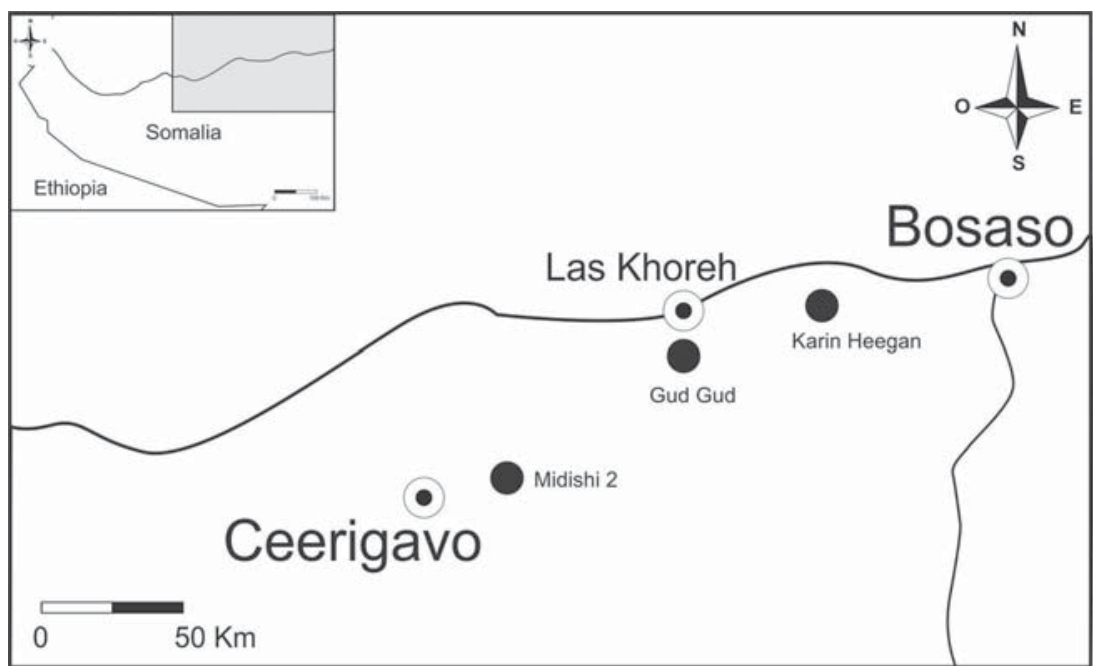

FIGURE 2. Sites excavated by S. Brandt in the north of Somalia during the early 1980s.

this time to the south. The Buur Ecological and Archaeological Project (BEAP) aimed to study human settlement and subsistence patterns during the late Pleistocene/Holocene in the Buur Heybe inselberg, $180 \mathrm{~km}$ northwest of Mogadishu. The largest shelter of this inselberg site had been excavated in 1935 by Paolo Graziosi, who named it Bur Eibe after the whole area (Graziosi 1940). The site was (more accurately) renamed as Gogoshiis Qabe and excavated by Brandt between 1983 and 1985, yielding one of the most extraordinary finds in the history of Somali archaeology: the skeletal remains of fourteen human individuals dating to the early Holocene, eleven of them still in primary position and with clear evidence of mortuary practices including stone cairns over the bodies and the deposition of kudu horns (Brandt 1988, 50). In 1985, two more individuals were recovered for a total of sixteen, providing the largest sample of prehistoric human remains in the Horn of Africa to this day.

Research in the Buur Heybe inselberg went on with the excavation of a second rock shelter (Guli Waabayo) between 1985 and 1989, uncovering the remains of another human individual of the same mid-Holocene chronology (Scheidegger 2013, 14). Unfortunately, most of the artifacts and human remains were destroyed during Somalia's civil war, which began in 1990. 
A few materials survived in the United States, where they had been taken for analysis and study by Brandt's students at the University of Florida in different Master and PhD dissertations (Solomon 2006; Scheidegger 2013), but these studies were never published.

In 1985, and parallel to the Buur Ecological and Archaeological Project, Brandt participated in a less well-known initiative: the JESS (Jubba Environmental and Socioeconomic Studies) Project, which resulted in a series of reports dedicated to analyzing the potential impact of the construction of the Baardheere Dam and Reservoir on the Jubba river within the bigger scheme of a development plan for the Jubba valley (Brandt et al. 1986; Brandt and Gresham 1988; 1989a; 1989b; 1990). The development plan included a five-year archaeological project to survey and document the area that would be affected by the planned reservoir. The results of this five-year project (Brandt and Gresham 1989a) remain largely unknown and understudied even though much of the documentation has been available online until recently and shows huge potential for advancing our archaeological knowledge of Somalia. During the fieldwork campaign of 1987 the three survey teams documented 686 sites in an area of 420 square $\mathrm{km}$ (Brandt and Gresham 1989a, 321-22). Even assuming that most of the sites consisted of open-air scatterings of lithic tools (394) and ceramics (100) and that several cemeteries of historical interest had previously been recorded, the results are astonishing. The findings included 160 cairns and eleven rock art sites currently omitted in the rock art studies for the region. Even considering the aridity of a 483-page grey literature report, the JESS project includes a remarkable amount of information-maps, drawings, chronological classifications - that is still waiting for proper integration within the general framework of Somali archaeology.

Brandt's pioneering work is complemented by that of Margherita Mussi, who in 1973 presented her PhD dissertation (Mussi 1971-72) at the Department of Humanities and Philosophy at the University of La Sapienza (Rome), based on the study of Somali archaeological materials stored at different museums and universities in Italy and the United Kingdom. Mussi $(1973 ; 1975)$ published several state-of-the-art articles with overviews of the Somali Stone Age and of previous Quaternary research. In March 1982, Mussi launched a project in the middle Jubba Valley with the Somali Academy of Sciences 
and Arts. The selected areas - around Luuq and north of Baardheere-were chosen due to the planning of the aforementioned dam (Mussi 1982) and the likely flooding of the area. A significant number of MSA and LSA sites were found, along with tumuli made of earth or covered with stones.

As a result of this survey, Mussi $(1984,18)$ excavated two tumuli in Hilo Ari later that year, providing relatively modern chronologies of about 200 years ago, coincident with the dating of the tumuli excavated decades ago by I. M. Lewis (1961) at Gan Libah. In 1983, an excavation was started in Buur Medow, a small hill close to Luuq and two kilometers away from the Jubba River, where a significant number of LSA tools were collected in a grid area of thirty-six square meters. At the top of the hill five square meters of this grid were excavated to the bedrock (just twenty centimeters deep), yielding in situ materials and a blackened area that could have corresponded to a hearth (Mussi 1988, 341). A total of 3,358 lithic products were collected in the excavation and the grid area, thus assigning Buur Medow to the LSA wet phase that occurred at the beginning of the Holocene in the Horn of Africa (10,000-4,000 BP).

The excavation of Buur Medow 1 in 1983 (Mussi 1987; 1988) was followed by surveys in the environs of Luuq in 1985, revealing several sites of similar chronology, one of which (Buur Ad) was thoroughly studied in 1985 (Mussi 1989). The combination of geological and archaeological analyses in the region (Mussi 1990; Abdirahim, Mohamed, Carmignani, and Coltorti 1993; Coltorti and Mussi 1993) led to the identification of a group of specific lithic industries with typological, technological, and stylistic characteristics not found elsewhere. The research team termed the complex "Luuqian industries" and proposed a chronology of 10,000-5,000 years BP (Coltorti and Mussi 1993, 469-70).

Whereas Brandt's and Mussi's projects were mainly research oriented, the third promising initiative launched in the 1980s had a different scope and purpose. Following the visit of a Somali delegation to Sweden in 1981 to express concern about the protection of Somalia's heritage, the Swedish Agency for Research Cooperation with Developing Countries (SAREC) agreed to support a mission with the objectives of training personnel, updating the heritage legislation, building-up a museum organization, initiating the mapping and registering of archaeological sites and monuments, and 


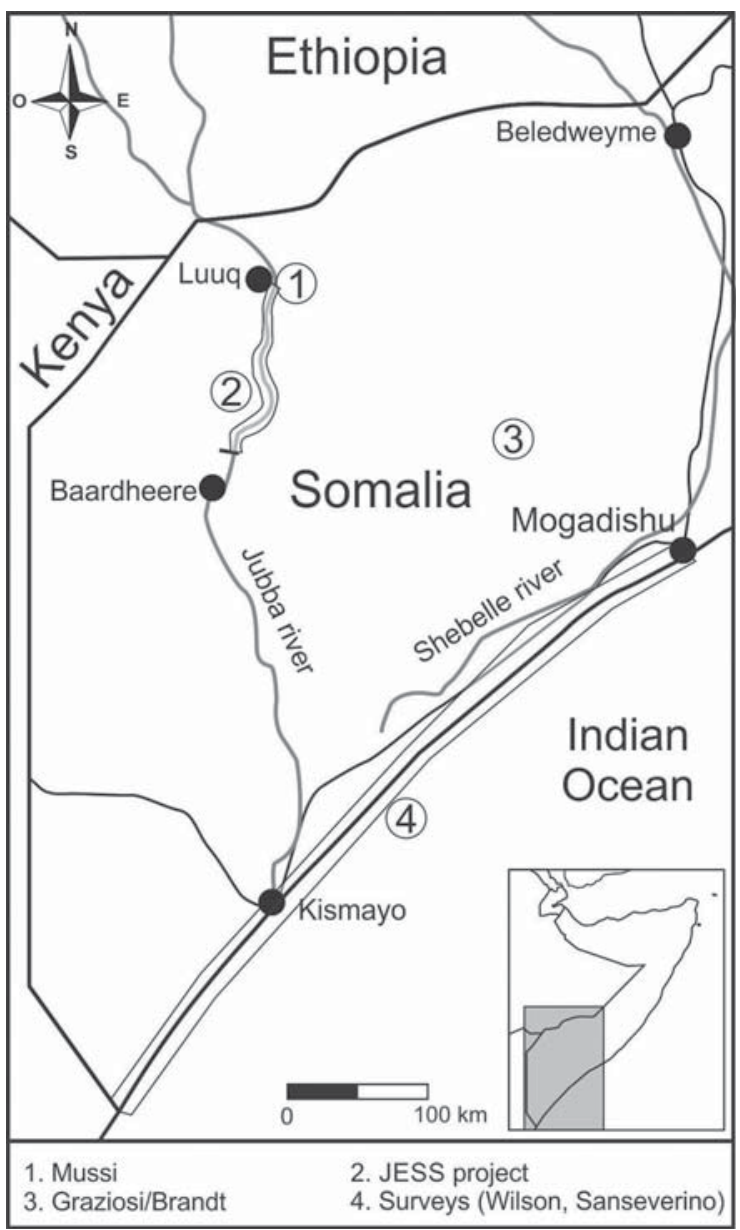

FIGURE 3.

Archaeological projects in the south of Somalia (1980s).

setting up an organization responsible for the supervision of the country's ancient monuments at the national, regional and local levels (Jönsson $1983,6)$. The scope of the project indirectly points up the complete lack of infrastructure dedicated to the study and preservation of the Somali heritage at the beginning of the 1980s.

Organized by the Swedish Central Board of National Antiquities and conducted by Sune Jönsson beginning in 1982, the project first sought the advice of those archaeologists who had recently worked or were starting to work in the country. During his three-month stay in Somalia, Jönsson briefly joined Brandt's expedition, which was excavating Medishe and surveying the 


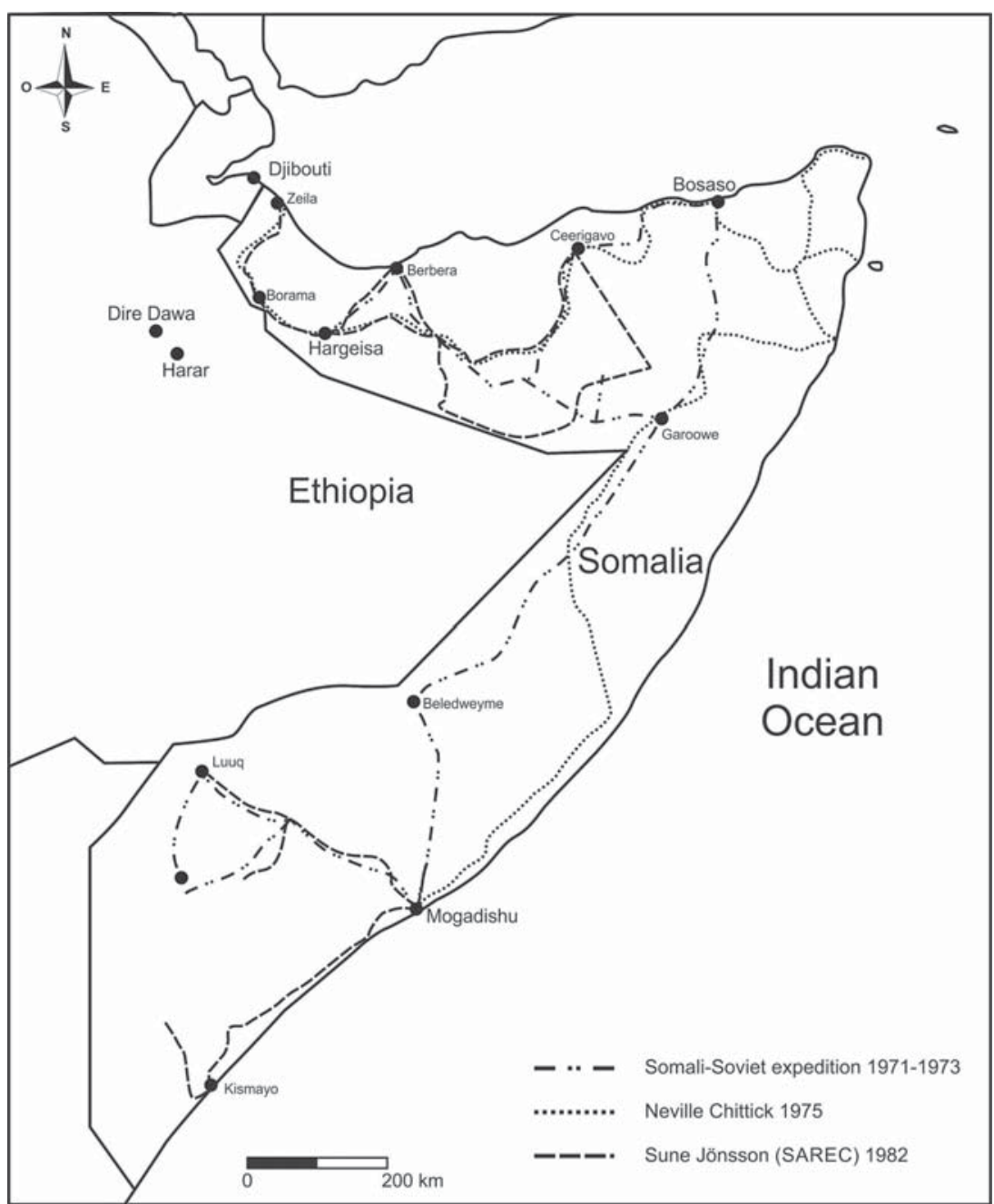

FIGURE 4. Archaeological expeditions in Somalia (early 1970s to early 1980s).

districts around Hargeisa, Sheikh, and Erigavo in the north; accompanied Mussi at the start of her survey around Baidoa, Luuq, and Dinsor; and made a third trip back to the north to train a student while conducting research around Elayo and El Afwein (Jönsson 1983, 30).

Beyond his brief fieldwork, Jönsson made a serious attempt to lay the foundations for a national inventory of archaeological sites for Somalia, which included the development of the first site cards based on the Standard 
African Site Enumeration System (SASES) elaborated by C. M. Nelson in the seventies (Jönsson 1984, 3). Jönsson also struck agreements with the Somali Academy of Sciences and Arts (SOMAC) and persuaded the different research groups working in Somalia to incorporate Somali students in their fieldwork teams and to send them to Europe and the United States for further professional training. Jönsson's efforts seem to have been successful, at least initially: in 1983 there is a reference to students being trained in the United States, India, the UK, and Italy, a cohort of young Somalis who might have provided the foundation for a future archaeological and museological service in Somalia (Jönsson 1984, 1-2).

Unfortunately, since 1983 there has been no further information about this promising project and it is not clear if the guidelines provided by the SAREC were followed by the SOMAC. What is clear is that the collaboration between Sweden and Somalia went on through the training of students in archaeology. The most remarkable of these students is Ahmed Dualeh Jama, who published his PhD on Mogadishu and the Benadir coast in 1996 (Dualeh 1996). Using his $\mathrm{PhD}$ we can partially reconstruct the activity of the SAREC after Jönsson's trip to Somalia. Dualeh worked in 1984 with Neville Chittick at the site of Biyo Guure, close to Berbera; an excavation poorly known (Chittick 1984, 17; Dualeh 1996, 39) due to the death of Chittick that same year. Between 1986 and 1990 Dualeh worked with several archaeologists - Paul Sinclair, David Damell, Lars Redin, and Anders Broberg, among others - under the umbrella of the SAREC (Dualeh 1996, 41-82). This work included surveys in Barawa (1986), Gezira (1986; 1988), Mogadishu town and surrounding region (1988) and the interior of the Benadir coast (1986; 1990). Three main excavations were also conducted during that period: the Shangani mosque at Mogadishu in 1986 (Dualeh 1996, 61-70; Broberg 1995), at the Hamar Jajab quarter, also in Mogadishu, in 1989 (Dualeh 1996, 71-74); and in Afgoi in 1990 (Dualeh 1996, 75-76).

Probably the most important intervention of this period was the excavation in the Shangani Mosque in Mogadishu, conducted by Ahmed Duale and Anders Broberg in 1986 with some assistance from the UNESCO (Khalil 1986). Found accidentally during the building of a new mosque (Dualeh 1996, 61), the excavation reached a depth of five meters and uncovered nine superimposed layers beginning sometime prior to the eleventh century 
and reaching to the nineteenth century before its abandonment (Dualeh 1996, 62). The ceramics of the Shangani Mosque were the first ones to be recovered in a rescue excavation in Somalia and were thoroughly studied by Paul Sinclair (1990), which so far constitutes the only published pottery assemblage in southern Somalia.

UNESCO'S collaboration in the excavation of the Shangani Mosque was also noteworthy. The UNESCO's relationship with Somalia had started as early as 1966 but was especially active by the end of the 1970s with the visits of several consultants in 1978 and 1979 (Khalil 1986, 1). These missions were especially focused on the development of museum infrastructures. Lufti A. Khalil visited the two existing museums in Mogadishu and wrote a report on their conditions and on the state of antiquities development in Somalia in general (Khalil 1986). Another three-week trip in 1987 resulted in a report for the Somali government with advice on the preservation and the presentation of the country's cultural heritage-especially Mogadishu architecture-as well as on the training needs of the Somali National Museum and Antiquities Service. The mission also reported on the preparation of two exhibitions in the recently opened National Museum (Crespo-Toral 1988).

The UNESCO report is interesting as it summarizes the state of the heritage and archaeological fields in Somalia well into the 1980s. Although not hesitating to point out the numerous deficiencies in museum displays, staff training, and legislative framework (Crespo-Toral 1988, 5-6, 10-13), the report also remarks on two fundamental initiatives in the protection and preservation of the Somali heritage: the preparation of an Antiquities Law, which was in its final stages prior to official approval in 1987, and the founding and installation of the National Museum, whose exhibitions were opened to the public in May 1987 (Crespo-Toral 1988, 4). The National Museum replaced the old Garesa Museum (which had been established by the Italians during the colonial period) and had its ground floor dedicated to archaeological and ethnographic exhibitions. The list of contributors to the archaeological section (Crespo-Toral 1988, 4) identified all the archaeologists who had been working in Somalia since the 1970s (discussed above). Despite its limitations (Crespo-Toral 1988, 5-6), the new Museum reflected significant developments of archaeology in Somalia from the mid-1970s to the mid-1980s. 


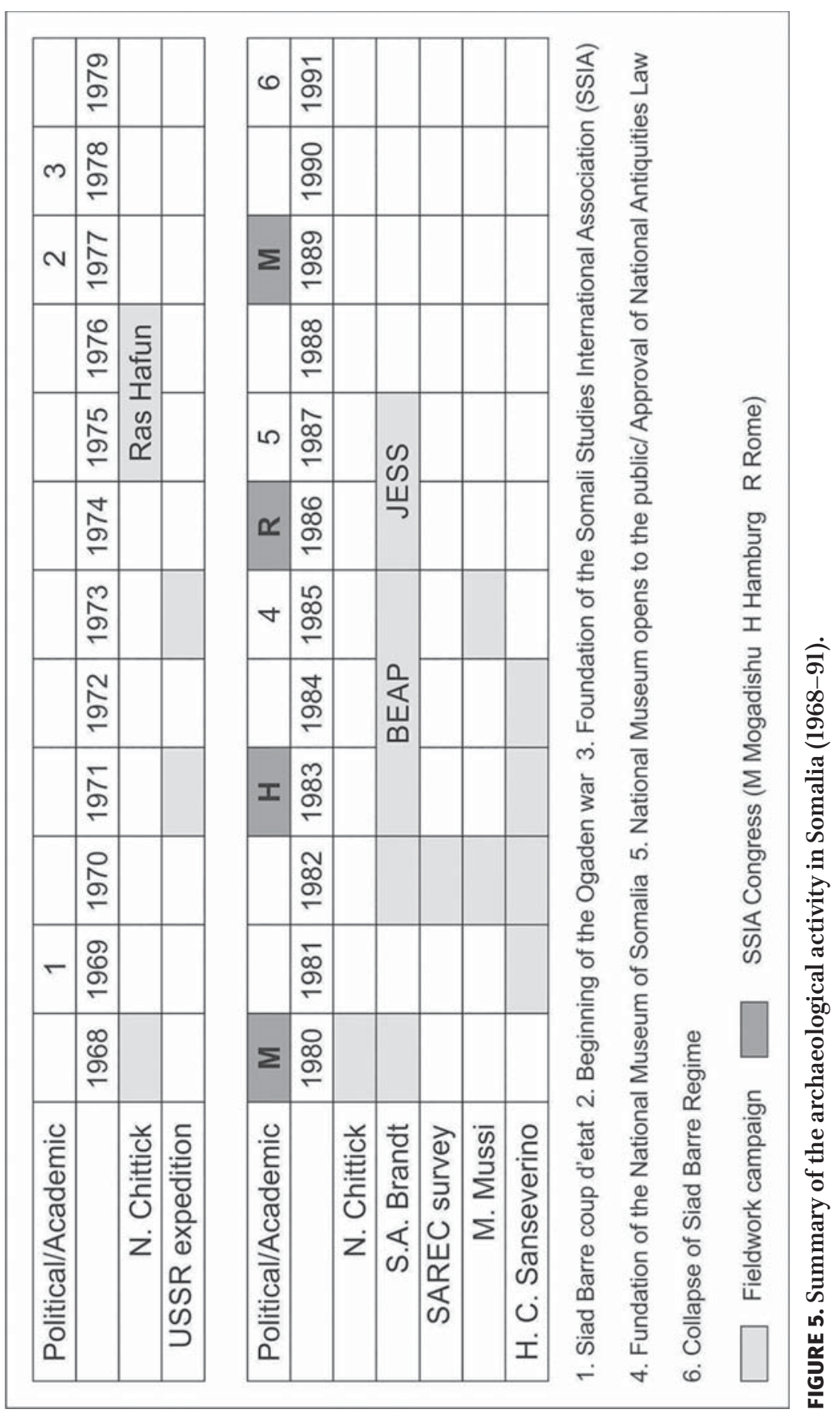


By the end of the 1980s the prospects of archaeology in Somalia seemed encouraging. The on-going projects were laying the foundations for longterm research in the country through the involvement of $\mathrm{PhD}$ students who could potentially continue and expand previous projects or develop new research directions in the discipline. Although well behind other countries such as Kenya or Ethiopia, the Somali government had started to show some interest in the preservation of its archaeological heritage, preparing an Antiquities Law, developing some basic infrastructures to store and display the objects, and initiating the training of staff with the help of the SAREC. Although some criticisms can be made to the ways these advances were planned and executed (Mire 2011, 77), the steps towards a more regulated and active archaeological practice in Somalia were evident.

\section{Somalia's Collapse and Somaliland's Archaeological Recovery}

The collapse of the Somali state in 1991, followed by civil war and failed international interventions, ended this small archaeological renaissance. In fact, political instability had already become widespread in northwest Somaliland since the mid-1980s, which probably explains why the only excavations and surveys in the late 1980s took place in southern Somalia. In 1988, a full rebellion started in the former British Somaliland and the Majertenia (northeastern Somalia), and the final breakdown of Siad Barre's regime in 1991 led to the division of Somalia into at least three different autonomous regions. In the northwest the former British Somaliland declared itself independent as the Republic of Somaliland, and started a long process of reorganization and reconstruction, which turned this region into the most stable part of Somalia for the last twenty-five years. The northeastern part of Somalia named itself Puntland and has remained an autonomous, relatively stable region within Somalia. The southern regions, however, have seen the worst of the civil war and the series of UN, U.S., and Ethiopian interventions that continue to the present day.

It is not surprising that the collapse of the Somali state paralyzed all archaeological activity in the country and invariably affected the still weak institutions that looked after Somali heritage. There are not many reliable 
reports on what happened to the collections of archaeological materials that were stored at the National Museum of Mogadishu, but they were lost at some point during the early 1990s. Virtually all of the materials and soil samples recovered by Steve Brandt in the BEAP project were destroyed as war engulfed Mogadishu (Jones, Brandt, and Marshall 2017, 57), although portions of the Museum's public collections were preserved and exported with the authorization of the Somali Academy of Sciences, and are currently curated at different U.S. universities (57). Other collections must have followed a similar fate, and we do not know of materials evacuated to other countries such as Sweden, where collaboration went on with some Somali students after the 1991 outbreak. This effort yielded some fruits in 1996, when the first Somali awarded with a $\mathrm{PhD}$ in archaeology completed a dissertation based on the study of Mogadishu and the surrounding area (Dualeh 1996).

For the following decades and to this day, archaeological work remains unfeasible in most of Somalia, and only in the self-declared state of Somaliland did political and social conditions allow a slow recovery of the research, especially since 2001 when the new constitution was approved and the state ministries began to function more effectively. In 2001, François Xavier Fauvelle-Aymar and Bertrand Hirsch briefly visited western Somaliland as part of a wider research on Islam in the Horn of Africa (Fauvelle-Aymar and Hirsch 2011, 5). The places visited (27-74) were Zeila, Amud, and Abassa to the west and Sheikh and Berbera to the east, and included the excavation of several test pits in Zeila, the collection of archaeological materials, the recording of the structures, and an accurate historical contextualization of the Islamic sites in the region through the use of primary and secondary sources. Although many of these places had been visited in the decades previous to the war by British, Swedish, and Soviet archaeologists, FauvelleAymar and Hirsch's work is the first one that places these sites in a proper historical context, linking them with the Islamic sultanates that controlled the region from the thirteenth to the sixteenth century.

However, the project that raised the profile of Somaliland archaeology and revealed its tremendous potential was the one launched in 2002 by Xavier Gurtherz and his colleagues at the Paul Valéry University (Toulouse), part of a wider investigation on the origins of food production in the Horn of Africa (Gutherz, Cros, and Lesur 2003a). While surveying the central 


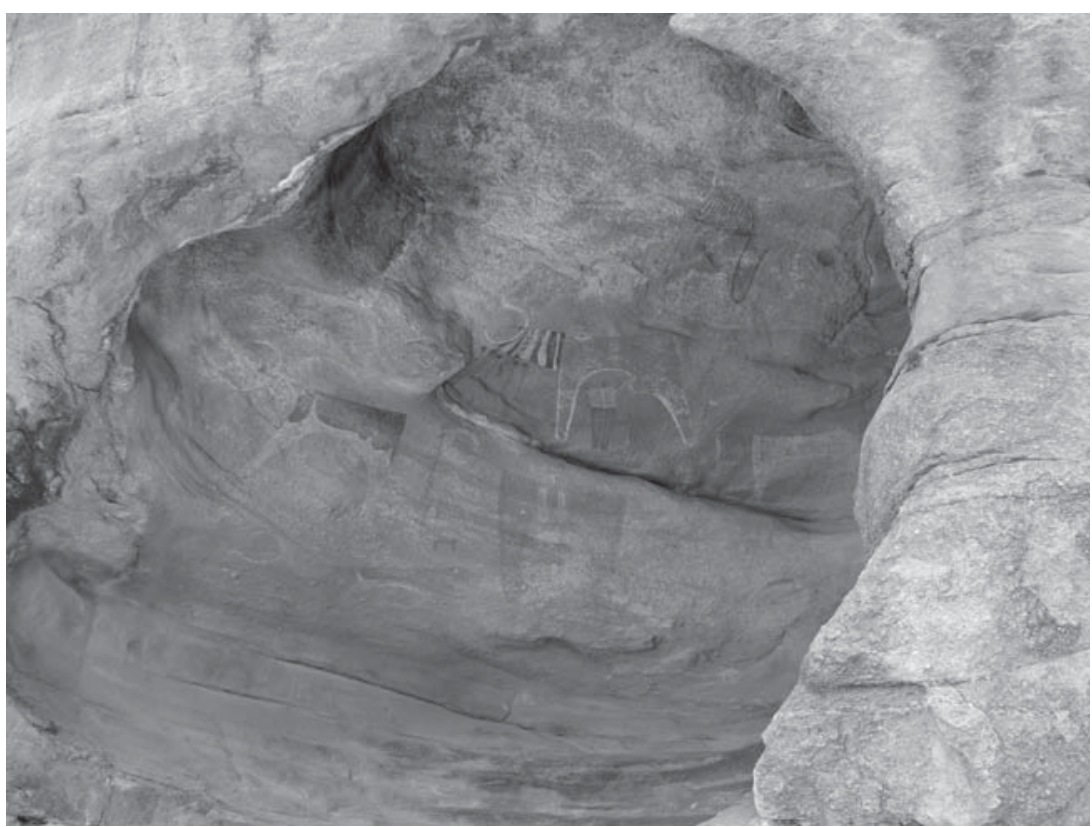

FIGURE 6. Paintings at Laas Geel.

region of Somaliland in search of caves and shelters with archaeological potential, the research team was led by local guides to a rocky outcrop that had one of the most impressive rock art samples in the Horn of Africa. The site, known as Laas Geel ("the place to water the camels"), consisted of twenty-two shelters with extremely well-preserved depictions of human figures, cows, and a few other wild and domestic animals. Excavations were conducted in two of the shelters (Gutherz et al. 2014) during several campaigns between 2003 and 2010, revealing two phases of occupation in the middle and late Stone Ages. Parallel to the excavation of the shelters, a thorough study of the rock paintings was conducted (Gutherz et al. 2003a; $2003 \mathrm{~b}$ ) including the use of 3D scans on some of the main shelters (Grenier, Antoniotti, Hamon, and Happe 2013). As a result of the collaboration between the French archaeologists and the Somaliland government, a small visitor's center was built in Laas Geel with Danish funding (Gutherz and Jallot 2011).

The discovery of Laas Geel not only represented a major archaeological benchmark in the history of Somalia/Somaliland. It also opened a debate 
about Somaliland's heritage and the need of proper strategies and structures to preserve it and use it as a touristic resource in the country. In this context of increasing archaeological activity and awareness in Somaliland, the contributions of Sada Mire proved invaluable. A Somali refugee raised in Sweden and educated in the UK, this young archaeologist visited Somaliland in 2007 to gather information for her $\mathrm{PhD}$ thesis and started an active collaboration with Somaliland authorities, which led to the establishment of a Department of Archaeology the same year, followed by the development of a series of surveys throughout the country and the hiring of staff in the countryside to monitor the most important archaeological sites (Mire 2015, 112-14). Sada's activity included the inventorying of many sites already known by the authorities of Somaliland but never properly recorded, as well as the identification of several more sites thanks to the collaboration of the local population (Mire 2008). Her archaeological work was accompanied by an active dissemination campaign in the media (Mire 2015, 114) that attracted attention to the delicate situation of Somaliland's heritage and raised awareness in both the Somaliland population and in the Somali diaspora (Mire 2007; 2010). Although the Department of Archaeology was merged with that of Tourism in 2010 — something that implied a significant reduction of funding - the interest of local authorities in the preservation of its heritage has been maintained with the installation of a small museum to keep the archaeological materials, and an incipient tourism industry has started around rock art and especially Laas Geel.

Despite scholarly attention to the work of Xavier Gurtherz and Sada Mire and the growing interest of local authorities and many Somalis both in the region and abroad, by 2012 archaeological fieldwork in Somaliland had come to a halt with the last French campaign, which aimed to 3D scan the most important shelters in Laas Geel (Grenier et al. 2013). Causes were varied: the lack of international recognition for Somaliland created extra difficulties to apply for funding, as well as problems to provide a legal framework for the archaeologists, including their insurances in an unrecognized state. It wasn't until 2015 when a new archaeological project was launched in Somaliland, conducted by the Institute of Heritage Sciences of the Spanish National Research Council (Incipit-CSIC). Part of a wider investigation of the characteristics of the historical trade networks along both coasts of the 


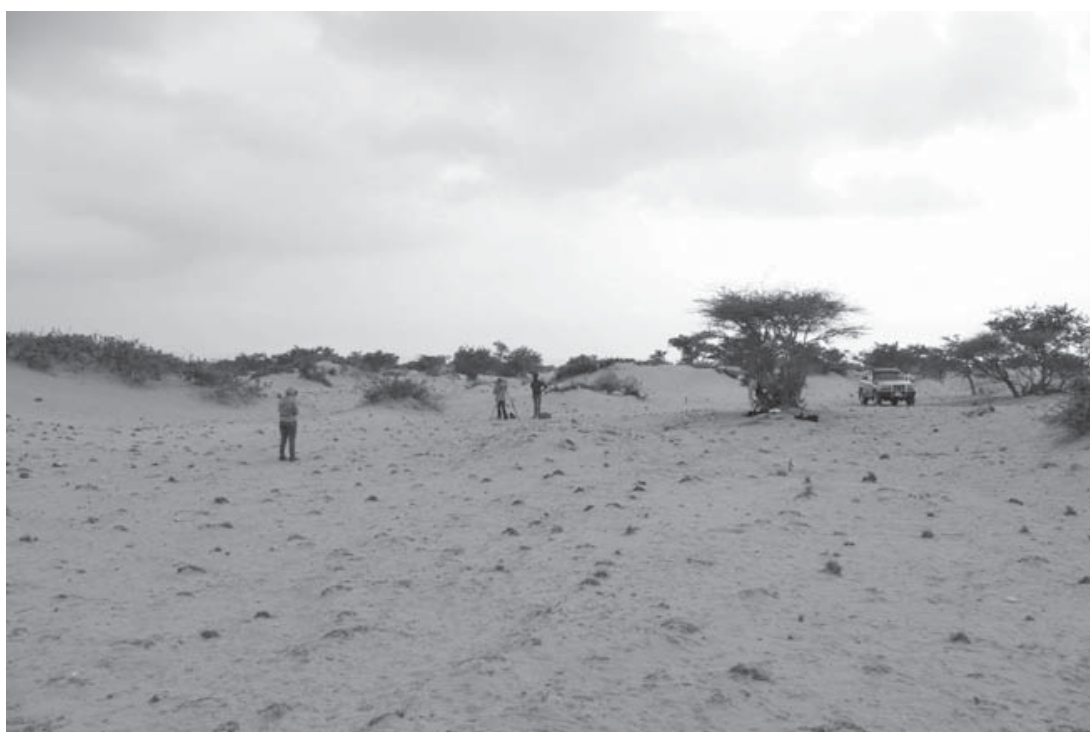

FIGURE 7. The Incipit-CSIC project documenting the archaeological site of Bender Abas (2016 field season).

Horn, the project gave special attention to the interactions between foreign traders and local communities and the ways in which the latter shaped and were shaped by the development of wider trade networks.

At the moment, the Incipit-CSIC project has conducted four fieldwork campaigns, the first one (2015) aimed at evaluating the characteristics of the country and the logistics required to undertake fieldwork in the region. During the 2016 and 2017 campaigns (González-Ruibal et al. 2017) the project combined visits to known but poorly documented sites with long-term excavations at important sites such as Bulhar (Torres et al. 2017). In 2018, the project visited eastern Somaliland for the first time, surveying the important archaeological site of Heis, and has continued its research on the medieval sites in western Somaliland that were part of the Sultanate of Adal in the sixteenth century (Torres, González-Ruibal, Franco, and Dualeh 2019). So far, thirty places have been exhaustively documented and seven of them have been archaeologically tested. In addition, more than 200 cairns have been geo-referred with GPS and in some cases fully documented through photogrammetry techniques. The chronology and physical characteristics of the studied sites vary considerably, from shell middens tentatively ascribed 


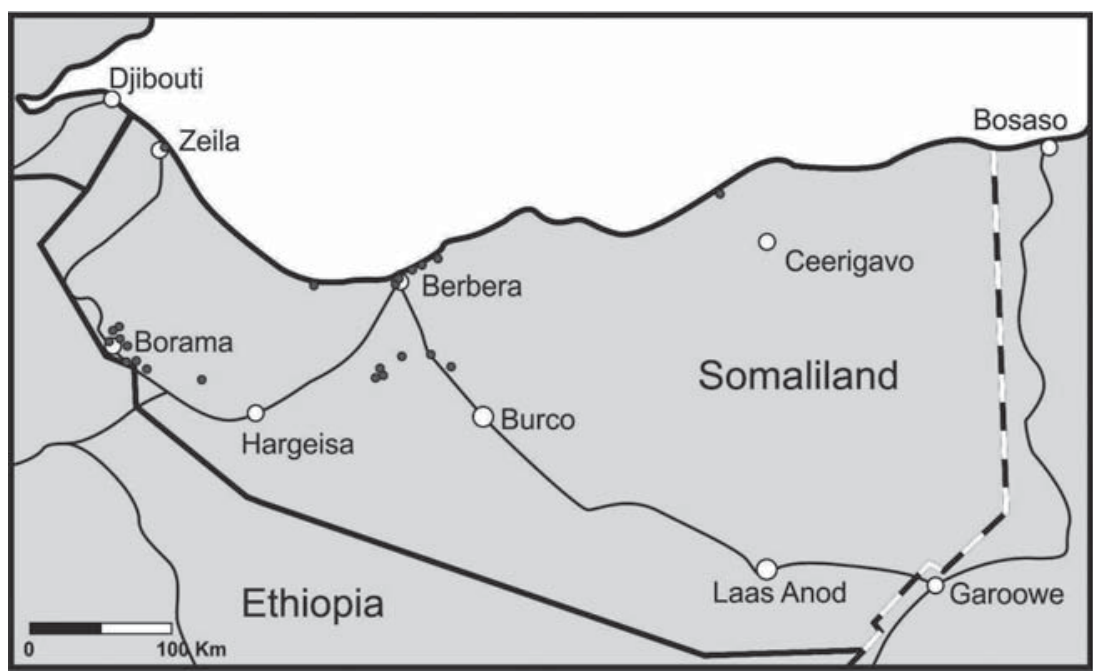

FIGURE 8. Sites surveyed/excavated by the Incipit-CSIC project between 2015 and 2018.

to the late Neolithic to Ottoman coastal towns such as Bulhar, although most of the sites studied so far could be identified as medieval, probably related to the Ifat and Adal sultanates that controlled the area between the thirteenth and the sixteenth century (González-Ruibal and Torres 2018).

Although still in its initial stages, the Incipit-CSIC has already moved beyond its original scope of research and has started a more comprehensive documentation of the Somaliland heritage with the systematic identification of cairns and other archaeological sites through the use of satellite images, the study of archaeological collections kept in museums and archives, and the critical analyses of primary sources to contextualize the historical processes in the region. It has also helped to promote parallel initiatives such as the MEDLANDS project, an EU-funded fellowship to study the interactions between nomads and urban dwellers in western Somaliland during the medieval period. ${ }^{1}$ It has also started a permanent collaboration with Somaliland institutions, including the training of personnel both in excavation techniques and museum management practices, and is actively supporting initiatives to disseminate and preserve the Somaliland heritage. Although these initiatives cannot replace the work of Somaliland institutions, they can ease the path for future teams and projects in the area. 


\section{Against the Odds: Challenges and Hope in the Archaeology of Somalia/Somaliland}

The results of more than a century of archaeological work in Somalia and Somaliland are difficult to evaluate. Although it is true that major political crises and cyclical civic unrest have repeatedly interrupted or halted many of the initiatives and projects conducted in the region, one of the objectives of this article is to present a longer-range and more balanced view of the history of archaeological research in Somalia/Somaliland. Although the region's troubled history has clearly hindered the development of a dedicated community of trained professionals and a network of supporting institutions necessary to sustain continuous archaeological research, in this author's view there are some encouraging lessons about how archaeology was and can be conducted in Somalia/Somaliland. The most obvious is the evidence that, in moments of relative political stability in the past, archaeology practice has generated popular and academic interest and managed to expand despite poor funding, complex logistics, and the fragility of local research institutions. Probably the best example was the decade of the 1980s, when the Somali government and its international supporters laid the foundations for a modern archaeology in Somalia. Though the state collapse in 1990 would subsequently destroy most of those foundations, we have witnessed over the past decade a revival of archaeological activity in Somaliland where several teams of archaeologists have been working almost continuously despite the complex situation in the region. During these brief periods of growth the quantity of archaeological data generated has been significant, even if the information has largely been neglected or underutilized by researchers working in neighboring regions of the Horn. This said, it would be naïve to dismiss the huge challenges that archaeological practice faces in Somalia, Somaliland, and neighboring countries. The challenges can be classified into three major categories: 1) the lack of institutional and legal frameworks to regulate the archaeological research; 2) a failure to articulate the significant academic questions to be approached from archaeology; and 3) the relatively low level of public engagement and local community awareness of the need to protect their own heritage. Given the current political situation of Somalia/Somaliland, the starting points for facing these challenges differ 
widely. With respect to the legal and institutional framework, Djibouti and Ethiopia have appropriate legal frameworks, well established professional institutions that control archaeological practice, and facilities to store and study archaeological materials, even though the quality of these facilities can vary significantly. At the other end of the spectrum is Somalia, where previous institutions related to archaeology have virtually disappeared and, apart from the sporadic efforts by a few small NGOs and a handful of dedicated local conservationists, there is little prospect for improvement in a mid- or long-term perspective. Somaliland, in contrast, is taking small but encouraging steps towards the protection of archaeological and historical heritage. The ongoing redaction of an Antiquities, Monuments and Museums Act, which should soon be presented to the Somaliland Parliament will provide, for the first time, a legal framework for the protection of the heritage of that territory, whereas the refunding of the Department of Archaeology in late 2017 (for many years the responsibility of archaeological work was managed from the Department of Tourism) has created a more stable and professional environment for the archaeological practice. Although lacking trained personnel, proper funding, and facilities to store, study, and display archaeological materials, these small steps, supported by the Incipit-CSIC staff, can set the foundations for a proper management and protection in Somaliland heritage.

In terms of academia, the situation of Somalia/Somaliland archaeology is somewhat paradoxical. The amount of published data is significantly higher than what might be expected considering the recent history of the region. Although much of this information is difficult to find, often appearing in old or poorly disseminated publications or short-run volumes found only in a few specialized libraries. It is also the case that that this limited but valuable corpus of information has, with a few exceptions, been underused and poorly integrated in larger contexts and interpretative frameworks. Considering the importance of the Somali regions for understanding key historical dynamics in the Horn of Africa and in wider geographical arenas of the Red Sea, Middle East, and Indian Ocean worlds, it is surprising how little is known about the archaeological evidence that does exist.

Fortunately, this situation appears to be changing, and in the last few years some steps have been taken towards integrating archaeology in the 
Horn of Africa into supranational interpretative frameworks. Probably the most significant advances have been made in the study of the medieval polities, which rose between the twelfth and sixteenth centuries in the region and that for many years had been viewed from the perspective of Islamic studies (Trimingham 1952; Couq 198; Braukämper 2002), with scarce archaeological references (Azäis and Chambard 1931; Curle 1937a). It was not until the late 1990s that a new series of projects directed by Bernard Hirsch and François-Xavier Fauvelle-Aymar revived interest in the medieval period in the Horn of Africa and laid the foundations for a better integrated approach (Fauvelle-Aymar and Hirsch 2008; 2011a), which included a significant use of archaeological (Fauvelle-Aymar, Hirsch, et al. 2006; Fauvelle-Aymar, Bruxelles, et al. 2006) and other material sources such as epigraphy (Fauvelle-Aymar and Hirsch 2011b). The new studies also included the first updated information about Somaliland, where the last information about the medieval period had been published in the 1980s.

The work initiated by Hirsch and Fauvelle-Aymar has been continued by Timothy Insoll, who in 2003 published a book on the archaeology of Islam in sub-Saharan Africa with a specific chapter on the Islamic Horn (Insoll 2003). Insoll has recently completed a long-term archaeological project based in Ethiopia and focused on Islam in the important cities of Harar and Harlaa (Insoll, Tesfaye, and Mahmoud 2014; Insoll, MacLean and Engda 2016; Insoll 2017), but he pays considerable attention as well to the role of trade networks in the history of Harar and its hinterland. Combined with the Incipit-CSIC project in Somaliland (González-Ruibal et al. 2017; González-Ruibal and Torres 2018; Torres et al. 2019), the possibility of a coordinated, transnational study of one of the most important periods in the Horn of Africa is becoming a reality. Although we cannot expect new fieldwork from Somalia at the moment, some of the available data for southern Somalia is currently being integrated in regional contexts and reinterpreted within the Swahili cultural context (Baumanova 2018).

A similar effort at the integration of archaeological data from the Horn is also underway in studies of the history of animal domestication and the spread of livestock in Africa, and here evidence from Somaliland and Somalia can play a decisive role (Blench and McDonald 2000; Gifford-Gonzalez and Hanotte 2011). The study of domestication and food production processes 
was the main reason for the reactivation of archaeological research in Somaliland after 2000 , and since then a systematic effort to analyze and integrate regional data for this key period in the history of the Horn of Africa has been undertaken by the team directed by Xavier Gutherz (Gutherz 2008; 2013; Gutherz et al. 2015; Lesur, Hildebrand, Abawa, and Gutherz 2014). Their research combines paleoclimatic with archaeological evidence from the Horn, including the study of rock art depictions. Although rock art has been a recurrent topic in Somalia/Somaliland studies (Burkit and Glover 1946; Clark 1954; Carder 1987; Bachechi 1998; Mire 2008), and Laas Geel is one of the main touristic attractions in the self-declared republic, the study of rock art in Somalia and Somaliland still requires a proper cataloguing of sites, styles, chronologies, and archaeological contexts. So far, the only thorough catalogue of rock art in the Horn of Africa was an open access $\mathrm{PhD}$ published in Spanish (Fraguas 2007) with limited dissemination; attempts to contextualize rock art in wider geographical contexts have been just as limited (LeQuellec 2009). The fact that the eleven shelters documented in the JESS project from the Jubba valley (Brandt and Gresham 1989a) have never been included either in catalogues or in academic studies is clear evidence for the need of a more systematic approach to this important topic.

There are two other research themes where Somalia/Somaliland can potentially play a significant role, even though the data in these cases are still too scarce to be properly integrated in the existing interpretative frameworks. The first theme is the role of the region in the trade during antiquity. Despite the identification of Roman materials at Xiis/Heis as early as 1882 (Revoil 1882; Desanges 1992; 1993) and the partial publication of evidence from the Ras Hafun site (Chittick 1976; 1979; Smith and Wright 1988; 1990), the dynamics of trade along the Somali coast during antiquity are yet not fully understood-although some general interpretations have been suggested (Horton 1996) and the known sites in the region are frequently mentioned in general discussions about Red Sea and Indian Ocean trade during that period (Seland 2014; Cobb 2015). In 2018, a preliminary survey of Xiis/Heis was conducted by the Incipit-CSIC, confirming the antiquity of the site and setting the ground for an archaeological campaign that will take place in early 2019. It is hoped that the results of this research will begin the long process of incorporating ancient Somalia/Somaliland archaeology into our 
understanding of Red Sea historical dynamics before the arrival of Islam to the Horn of Africa.

The second important but understudied topic is the archaeology of nomads in Somalia and Somaliland. Although some work has been done with regard to the classification and description of the numerous tumuli that dot the pastoral landscape (Chittick 1992), little is known about their chronology and cultural meaning. Although the tumuli are usually considered pre-Islamic, the fact that some of them have been built inside nomadic mosques or with two stelae on the top may reflect a process of Islamization of the nomadic populations, which probably took place during the medieval period. Again, with some exceptions (Davies 2013) not much has been done to integrate these archaeological remains within wider geographical and historical dynamics, despite their importance as the main material evidence of the nomadic communities that constitute the majority of the population in the region.

The ability to further explore these and related research topics will certainly require the establishment of political stability and the development of an appropriate institutional infrastructure, but progress also depends on the efficiency with which the existing resources are used. Although the destruction of Somalia's material heritage, including the archaeological collections formerly stored at the National Museum of Mogadishu, is a real tragedy, there are still large corpuses of surviving materials - archaeological, photographic, cartographic, and ethnographic — held in museums and other institutions around the world that can be consulted by those interested in the material past. In addition to holdings at the British Institute in East Africa, the British Museum, and the Oriental University of Naples, there are excellent collections of maps at the U.S. Library of Congress, and the series of aerial photographs taken by the Royal Air Force in the 1930s to delimit the border between Ethiopia and British Somaliland include some views of medieval sites such as Amud, now completely destroyed. Modern technologies like aerial surveys through satellite images enable us to identify cairns from our own homes, and existing collections of archaeological materials can be analyzed with new techniques such as composition analyses and integrated into new data sets through GIS technologies. Online collections of rock art like the one catalogued by the African Rock Art Image project 
(British Museum) provide hundreds of images for research and educational purposes. Combined with the slow but steady increase in the archaeological fieldwork in the region, the prospects of a viable Somali archaeology remain hugely challenging but not necessarily grim.

These prospects are directly related to the third main challenge for Somali archaeology: the battle to raise public awareness in Somali communities about their own heritage. In a region plagued with political uncertainty, low educational levels, lack of appropriate heritage experts and proper infrastructures, it may seem naïve to contemplate a national campaign for heritage preservation. However, Somaliland has demonstrated that it is possible to link historic preservation with its quest for international recognition. By promoting tourism to Laas Geel and to a lesser extent Berbera, Maduuna, and Zeila, Somaliland projects an image of peace and stability and demonstrates their value to the wider public. In the best-known case, Laas Geel, some of the most iconic figures are already being used as advertising symbols and incorporated into public discourse, helping to build the perception of heritage as a national good. The small but growing number of books being published (in both English and Somali) on the history of Somaliland, and other initiatives like the founding of the Somali Archaeology Association in 2018 and the opening of the Saryan Museum in Hargeisa in 2017 are also helping to build a social framework to support research and institutional development. Although the vast nomadic landscape has served to shelter and preserve much of Somaliland's rich archaeological heritage, increasing urban growth and rural impoverishment have contributed to the looting of many cairns and to the emergence of a black market in fake antiquities that threatens many of the main archaeological sites. That is the case of Amud, one of the most important medieval villages in the Borama area. In the 1930s, some of its old ruins stood two meters high; now they are completely destroyed, the stones used for the construction of new houses. As the construction of roads and other infrastructures advance in Somaliland, the need for a proper legal and social preservation strategy becomes ever more urgent.

Given these challenges, new technologies including Somaliland's excellent internet connectivity are becoming unexpected but extremely useful allies to promote the preservation of the archaeological and historical heritage. With a huge Diaspora deeply involved and committed to the development 


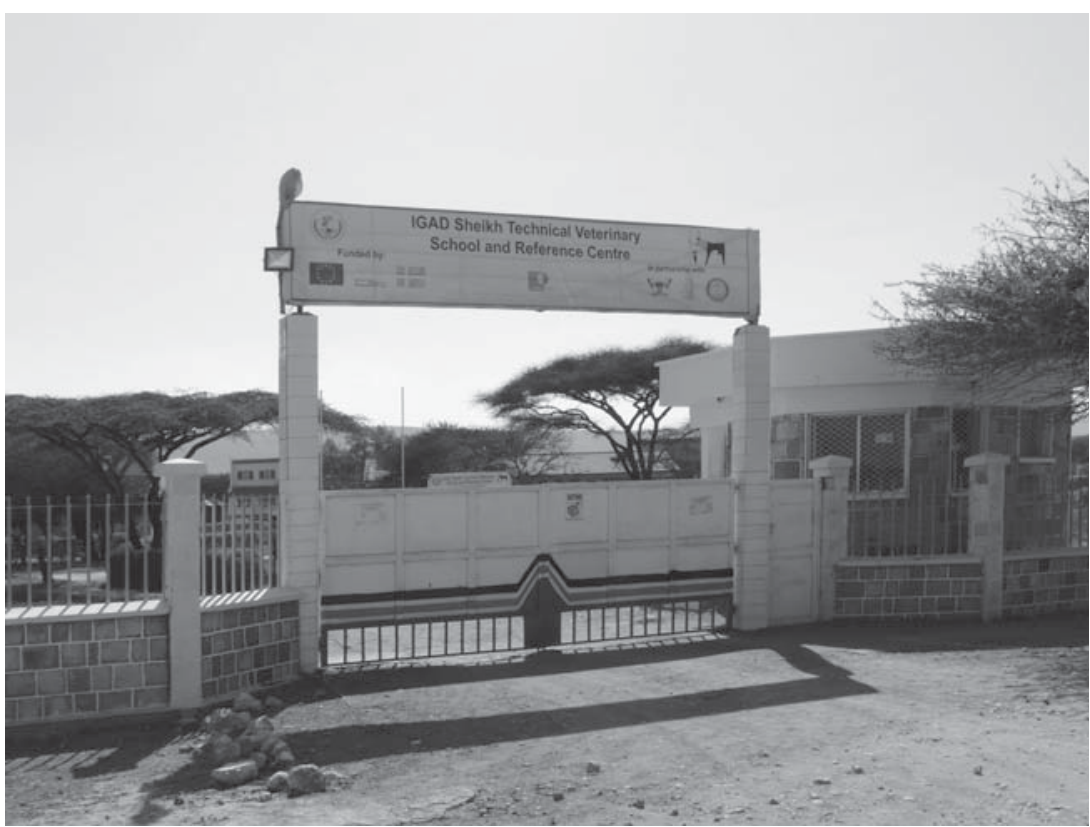

FIGURE 9. Veterinary school at Sheikh. The logo of the center is a reproduction of one the most important and better known Laas Geel paintings.

of its country, the use of social media platforms like Facebook and Twitter act as a key tool to raise awareness and to engage Somalis young and old with their own heritage. The important role played by Sada Mire in using social media ${ }^{2}$ has been recently complemented with other initiatives like the aforementioned Medieval Landscapes project or the Twitter account of the Incipient-CSIC project. ${ }^{3}$ Even in Somalia, where conditions are less stable, some digital initiatives have been launched to preserve images, photographs, and other documentation related to the Somali heritage. ${ }^{4}$ Although these developments are no substitute for vigorous preservation policies conducted by governments, they nevertheless help to create and expand public concern about heritage preservation.

As globalization advances, it is hoped that growing public awareness of the importance of material heritage will prompt new local, African continental, and international initiatives to support archaeological practices in the safer regions of the Horn in the coming decades. The task ahead is undoubtedly demanding, but the steady pursuit of Somali archaeology 
promises to yield a deeper understanding of the dynamic early history not only of the Horn of Africa, but of the African continent as a whole.

\section{REFERENCES}

Abdirahim, M. M., A. M. Mohamed, L. Carmignani, and M. Coltorti. 1993. "The Geomorphological Evolution of the Upper Jubba Valley in Southern Somalia." In Geology and Mineral Resources of Somalia and Surrounding Regions, 241-50. ReIazioni e Monografie 113. Firenze, Italy: Instituto Agronomo Oltremare.

Allen, J. de V. 1992. "Peopling of the Lamu-Southern Benaadir Hinterland in the 14th-17th Centuries." In Proceedings of the First International Congress of Somali Studies, Mogadishu, edited by H. M. Adam and C. L. Geshekter, 2-24. Atlanta, GA: Scholars Press.

Azaïs F. and R. Chambard 1931. Cinq Années de recherches archéologiques en Éthiopie. Paris: Paul Geuthner.

Bachechi, L. 1998. "Contributo alla conoscenza dell' arte rupestre somala." Rivista di Scienze Preistoriche 49: 225-246

Baumanova, M. 2018. "Pillar Tombs and the City: Creating a Sense of Shared Identity in Swahili Urban Space." Archaeologies 14: 377. doi:10.1007/s11759-018-9338-x

Blench, R. M. and K. C. MacDonald, eds. 2000. The Origins and Development of African Livestock: Archaeology, Genetics, Linguistics and Ethnography. London: University College London Press.

Brandt, S. A. 1986. "JESS Interim Report on Cultural Heritage Sites in Proposed Baardheere Reservoir Area." JESS Report No. 8. Unpublished report.

—. 1988. "Early Holocene Mortuary Practices and Hunter-Gatherer Adaptations in Southern Somalia." World Archaeology 20, no. 1: 40-56.

. 1992. "Importance of Somalia for Understanding African and World Prehistory." In Proceedings of the First International Congress of Somali Studies, Mogadishu, edited by H. M. Adam and C. L. Geshekter, 25-34. Atlanta, GA: Scholars Press.

Brandt, S. A. and G. A. Brook. 1984. "Archaeological and Palaeoenvironmental Research in Northern Somalia." Current Anthropology 25: 119-21.

Brandt, S. A., G. A. Brook, and T. H. Gresham. 1984. "Quaternary Paleoenvironments and Prehistoric Occupation of Northern Somalia." In Proceedings of the Second International Congress of Somali Studies, Vol. 2, edited by Thomas Labahn, 7-19. 
Hamburg, Germany: Buske.

Brandt, S. A., and T. H. Gresham. 1988. "JESS Report on Cultural Heritage Survey of

Proposed Baardheere Reservoir." Unpublished report.

_ 1989a. "Cultural Heritage Survey of Proposed Baardheere Reservoir." In Jubba

Environmental and Socioeconomic Studies, Vol. 3, 316-447. Unpublished Report.

_ 1989b. "An Archaeological Survey of the Proposed Baardheere Reservoir, Upper Jubba River, Southern Somalia." Nyame Akuma 32: 28-30.

- 1990. Phase II: Archaeological Investigations in the Proposed Baardheere

Reservoir, Upper Jubba River, Somalia. Florida: Foundation for African Prehistory and Archaeology, Center for African Studies, University of Florida.

Brandt, S., and N. Carder. 1987. "Pastoral Rock Art in the Horn of Africa: Making Sense of Udder Chaos." World Archaeology 19, no. 2: 194-213.

Braukämper, U. 2002. Islamic Principalities in Southeast Ethiopia between the

Thirteenth and Sixteenth Centuries. Islamic History and Culture in Southern

Ethiopia. Münster: LIT Verlag.

Broberg, A. 1995. "New Aspects of the Medieval Towns of Benadir in Southern Somalia." In Islamic Art Culture in Sub-Saharan Africa, edited by K. Ådahl and B. Sahlström, 111-22. Uppsala, Sweden: Acta Universitatis Upsaliensis.

Burkit, M., and P. E. Glover. 1946. "Prehistoric Investigations in British Somaliland."

Proceedings of the Prehistoric Society 12, no. 3: 49-56.

Burton. R. 1894. First Footsteps in Africa or an Exploration of Harar. (2 vols.) London:

Tylston and Edwards.Carder, N. 1987. "Modeling the Evolution of Pastoral Rock Art in the Horn of Africa." Unpublished master's thesis, Department of Anthropology, University of Georgia.

Carder, N. 1987. "Modeling the Evolution of Pastoral Rock Art in the Horn of Africa." M. A. thesis, Department of Anthropology, University of Georgia.

Cerulli, E. 1931. "Tradizionistoriche e monumentidella Migiurtinia." Africa Italiana 4: 153-69.

Chittick, H. N. 1969. "An Archaeological Reconnaissance of the Southern Somali Coast." Azania 4: 115-30.

_ 1976. "An Archaeological Reconnaissance in the Horn: The British-Somali Expedition, 1975." Azania 2: 117-34.

- 1979. "Early Ports in the Horn of Africa." International Journal of Nautical Archaeology 8, no. 4: 273-77.

_ 1980. "Pre-Islamic Trade and Ports of the Horn." In Proceedings of the 8th 
Pan-African Congress of Prehistory and Quaternary Studies, Nairobi, edited by R. E. Leakey and B. A. Nairobi: International Louis Leakey Memorial Institute for African Prehistory.

- 1982. "Medieval Mogadishu." Paideuma 28: 45-62.

_. 1984. "Somalia." Nyame Akuma 24/25: 17

_. 1992. "Cairns and Other Drystone Monuments in Somali Regions." In Proceedings of the First International Congress of Somali Studies, Mogadishu, edited by H. M. Adam and C. L. Geshekter, 35-42. Atlanta, GA: Scholars Press. Clark, J. D. 1954. The Prehistoric Cultures of the Horn of Africa. Cambridge: Cambridge University Press.

Cobb, M. 2015. "The Chronology of Roman Trade in the Indian Ocean from Augustus to Early Third Century CE." Journal of the Economic and Social History of the Orient 58: 362-418

Coltorti, M., and M. Mussi. 1993. "Hunter-Gatherers of the Middle Juba Valley, Southern Somalia, during the Early Holocene." In Environmental Change and Human Culture in the Nile Basin and Northern Africa until the Second Millennium B.C., edited by L. Krzyzaniak, M. Kobusiewicz, and John Alexander. Poznan Archaeological Museum, Studies in African Archaeology 4: 459-471.

Crespo-Toral, H. 1988. "Somali Democratic Republic. Museum Development and Monuments Conservation." Restricted Technical Report RP/1986-1987/XI.1.3. Paris: UNESCO.

Cuoq, J. 1981. L'Islam en Éthiopie des origines au XVIe siècle. Paris, Nouvelles Éditions Latines.

Curle, A. T. 1932. "An Excavated Chamber at Arorguddan, British Somaliland." Man 32: 54

_. 1937a. “The Ruined Towns of Somaliland." Antiquity 11: 315-27.

_. 1937b. "Carved stones,British Somaliland." Antiquity 11: 352-354.

Davies, M. I. J. 2013. “Stone Cairns across Eastern Africa: A Critical Review." Azania 48, no. 2, 218-40. doi:10.1080/0067270X.2013.789207

Desanges, J. 1992. “Le fonds Révoil du Musée de l'Homme. (Heïs, Somalie, 1881). Aperçus préliminaires." Revue des Études Anciennes 94-1-2: 99-105

Desanges, J., E. M. Stern, and P. Ballet. 1993. Sur les routes antiques de l'Azanie et de l'Inde. Le fonds Révoil du Musée de l'Homme (Heïs et Damo, en Somalie). Paris, Paillart Mémoires de l'Académie des Inscriptions et Belles-Lettres (new series) 13. 
Dualeh, A. 1996. The origins and development of Mogadishu AD 1000 to 1850: A study of urban growth along the Benadir coast of southern Somalia. Studies in African Archaeology 12. Uppsala: Uppsala University.

Evans, J. 1896-1897. “On Some Palaeolithic Implements Found in Somaliland by Mr. H.W. Seton-Karr." Proceedings of the Royal Society of London (1854-1905): 19-21.

Fauvelle-Aymar, F.X. and B. Hirsch 2008. "Établissements et formations politiques musulmans d'Éthiopie et de la corne de l'Afrique au Moyen Âge. Vers une reconstruction." Annales Islamologiques 42: 339-372.

Fauvelle-Aymar, F.X., B. Hirsch, L. Bruxelles, M. Chalachew, A. Chekroun, and A. Deresse 2006. "Reconnaissances de trois villes musulmanes de l'époque médiévale dans l'Ifat”. Annales d'Éthiopie, XXII: 133-178.

Fauvelle-Aymar, F.X., L. Bruxelles, A. Chekroun, R. Mensan, B. Hirsch O. Onezime, W. Asnake, A. Deresse, Z. Hailu and M. Ahmed, M. 2006. "A topographie survey and some soundings at Nora, an ancient Muslim town of Ethiopia." Journal of Ethiopian Studies, XXXIX (1-2): 1-11.

Fauvelle-Aymar, F.X., and B. Hirsch (eds) 2011. Espaces Musulmans de la Corne de l'Afrique au Moyen Age. Études d'Archéologie et d'Histoire. Paris: De Boccard/ Centre Français d'Études Éthiopiennes.

Fauvelle-Aymar, F.X., and B. Hirsch 2011b. "Muslim Historical Spaces in Ethiopia and the Horn of Africa: A Reassessment." Northeast African Studies 11 (1) (New Series: 25-53).

Fraguas, A. 2007. "Del panel a la hegemonía nuevas teorías y tecnologías para el arte rupestre del Noreste de Africa." PhD diss., Complutense University of Madrid, https://eprints.ucm.es/7545/

Freeman-Grenville, G.S.P. 1963. “Coins from Mogadishu, c. 1300 to c. 1700.” Numismatic Chronicle and Journal of the Royal Numismatic Society (Seventh Series) 3: 179-200.

Gifford-Gonzalez, D., and O. Hanotte. 2011. "Domesticating Animals in Africa: Implications of Genetic and Archaeological Findings." Journal of World Prehistory 24: 1-23.

González-Ruibal, A., J. de Torres, M. A. Franco, M. A. Ali, A. M. Shabelle, C. M. Barrio, and K. A. Aideed. 2017. "Exploring Long Distance Trade in Somaliland (AD 1000-1900): Preliminary Results from the 2015-2016 Field Seasons." Azania: Archaeological Research in Africa 52, no. 2: 135-72.

González-Ruibal, A., and J. Torres. 2018. "The Fair and the Sanctuary: Gathering Places 
in a Nomadic Landscape (Somaliland, 1000-1850 AD)." World Archaeology 50, no. 1: 23-40.

Graziosi, P. 1938. "L'età della pietrain Etiopia e in Somalia." Rivista delle Colonne 6: 929-49.

. 1940. L'età della pietra in Somalia. Firenze: Sansoni.

. 1954. "Misione Preistorica Italiana alla Somalia." Riviste di Scienze Preistoriche 9: 121-23.

Grenier, L., P. Antoniotti, G. Hamon, and D. Happe. 2013. “Laas Geel (Somaliland): 5000 Year-Old Paintings Captured in 3D." International Archives of the

Photogrammetry, Remote Sensing and Spatial Information Sciences 60, no. 5/W2: $283-88$.

Gutherz, X. 2008. "Aux origines de la production dans la Corne de l'Afrique: un champ d'étude à reconquérir." Archéologies de Provences et d'ailleurs: Mélanges offerts à Gaëtan Congès et Gérard Sauzade (suppl.) 5: 127-51.

— 2013. "Quel Néolithique dans la Corne de l'Afrique?" Archéo-Nil. Revue de la société pour l'étude des cultures prépharaoniques de la vallée du Nil 23: 73-90.

Gutherz, X., J. P. Cros, and J. Lesur. 2003a. "The Discovery of New Rock Paintings in the Horn of Africa: The Rock Shelters of Laas Geel (Republic of Somaliland)." Journal of African Archaeology 1, 227-36.

- 2003b. "Nouvelles découvertes de peintures rupestres dans la Corne de l'Afrique: les abris-sous-roche de Laas Geel, République du Somaliland." Annales d'Éthiopie 19, 295-306.

Gutherz, X., and L. Jallot. 2011. The Decorated Shelters of Laas Geel and the Rock Art of Somaliland. Montpellier, France: Presses Universitaires de la Méditerranée.

Gutherz, X., A. Diaz, C. Ménard, F. Bon, K. Douzed, V. Léa, J. Lesur, and D. Sordoillet. 2014. “The Hargeisan Revisited: Lithic Industries from Shelter 7 of Laas Geel, Somaliland and the Transition between the Middle and Late Stone Age in the Horn of Africa." Quaternary International 343: 69-84.

Gutherz, X., J. Lesur, J. Cauliez, V. Charpentier, A. Diaz, M. Omar Ismaël, J. M. Pène, D. Sordoillet, and A. Zazzo. 2015. "New Insights on the First Neolithic Societies in the Horn of Africa: The Site of Wakrita (Gobaad Basin, Djibouti)." Journal of Field Archaeology 40, no. 1: 55-68.

Horton, M. 1996. "Early Maritime Trade and Settlement along the Coasts of Eastern Africa." In The Indian Ocean in Antiquity, edited by J. Reade, 439-59. London: Kegan Paul International, in association with the British Museum. 
Huntingford, G. W. 1978. “The Town of Amud, Somalia." Azania 13, no. 1: 181-6.

Insoll, T. 2003. The Archaeology of Islam in sub-Saharan Africa. Cambridge: Cambridge University Press.

Insoll, T., H. Tesfaye and M. S. Mahmoud. 2014. "Archaeological survey and test excavations, Harari Regional State, Ethiopia, July-August 2014: A preliminary fieldwork report." Nyame Akuma 82: 100-109.

Insoll, T., R. MacLean and B. Engda. 2016. "Archaeological survey and test excavations, Harlaa, Dire Dawa, and Sofi, Harari Regional State, Ethiopia: A preliminary fieldwork report." Nyame Akuma 85: 23-32.

Insoll, T. 2017. "First Footsteps in the Archaeology of Harar, Ethiopia." Journal of Islamic Archaeology 4. no. 2: 189-215.

Jones, M. B., S. A. Brandt, and F. Marshall. 2017. "Hunter-Gatherer Reliance on Inselbergs, Big Game, and Dwarf Antelope at the Rifle Range Site, Buur Hakaba, Southern Somalia 20,000-5,000 BP." Quaternary International 471: 55-65.

Jönsson, S. 1983. Archaeological Research Co-operation between Somalia and Sweden: Report on a Three-Month Visit to Somalia in 1982. Stockholm: Swedish Central Board of National Antiquities.

Jönsson, S. 1984. "An Archaeological Site File of Somalia." In Proceedings of the Second International Congress of Somali Studies, Vol. 2, edited by T. S. Labahn, 7-19. Hamburg, Germany: Buske.

Josseaume, F. 1895. "Réflexions anthropologiques à propos des tumulus et silex taillés des Çomalis et des Danakils." L'Anthropologie 6: 393-413

Khalil, L. A. 1986. Somali Democratic Republic. Excavation of Shangani MosqueMuseum Development and Antiquities Preservation. Restricted Technical Report RP/1986-987/Xl.1.3. Paris: UNESCO.

LeQuellec, J. L. 2009. “Les arts rupestres dans le Rift.” In Le Rift est-africain, edited by B. Hirsch and B. Roussel, 343-58. Montpellier, France: IRD Éditions.

Lesur, J., E. A. Hildebrand, G. Abawa, and X. Gutherz. 2014. “The Advent of Herding in the Horn of Africa: New data from Ethiopia, Djibouti and Somaliland." Quaternary International 343: 148-58.

Lewis I. M. 1961. “The So-Called 'Galla Graves’ of Northern Somaliland.” Man 61: 103-6.

_ 2002. A Modern History of the Somali. Eastern African Studies. Oxford: James Currey.

Mire, S. 2007. "Preserving Knowledge, Not Objects: A Somali Perspective on Heritage Management and Archaeological Research." African Archaeological Review, 24, 
$49-71$.

. 2008. "The Discovery of Dhambalin Rock Art Site, Somaliland." African

Archaeological Review 25, nos. 3-4: 153-68.

- 2010. "Somaliland: Archaeology in a Breakaway State." Current World

Archaeology 43: 26-33.

- 2011. "The Knowledge-Centred Approach to the Somali Cultural Emergency and Heritage Development Assistance in Somaliland." Special issue, edited by F. Sulas. African Archaeological Review 29, no. 1: 71-91.

. 2015. "Mapping the Archaeology of Somaliland: Religion, Art, Script, Time, Urbanism, Trade and Empire." African Archaeological Review 32: 111-136.

Mussi, M. 1971-72. "Ecologia ed archeologia preistorica della Penisola Somala."

Universita degli Studi di Roma, Fac. Di Lettere e Filosofia. Tesi di laurea in ecologia preistorica. Unpublished ms.

— 1973. "La question de l'Acheuléen de la Somalie." Origini 7: 7-33.

- 1975. “Etat des connaissances sur le Quaternaire de la Somalie." Quaternaria 18: $161-83$.

. 1982. "Archaeological Survey in Southern Somalia." Nyame Akuma 20: 45.

. 1984. "Excavations in Southern Somalia." Nyame Akuma nos. 24-25: 18.

- 1987. "Buur Medow 1, a LSA Site in the Middle Juba Valley." Nyame Akuma 28:

33-37.

- 1988. "Buur Medow 1, a L.S.A. Site in the Middle Juba Valley (Southern

Somalia)." Proceedings of the Third International Congress of Somali Studies, vol. 4, 340-6. Rome: Pensiero Scientifico Editore.

— 1989. "The LSA industry of Buur Ad (Middle Juba Valley)." Nyame Akuma 31: $32-35$.

_. 1990. "Uomo e ambiente nella media valle del Giuba durante l’Oloceneantico." Biogeographia 14: 525-39.

Paulitschke, P. V. 1898. "Prähistorische Funde aus dem Somallande." Mittheilungen der anthropologischen Gesellschaft 28: 34-36, 115-21.

Pradines, S. 1999. "L'Archeologie Swahili et la collection Revoil au Musee de l'Homme, Paris." Bulletin for the Regional Centre for the Study of Archaeology in Eastern and Southern Africa 8: 20-28.

Révoil, G. 1882. La Vallée du Darror; Voyage au Pays Comalis. Paris: Challamel Ainé.

Sanseverino, H. C. 1983. "Reconnaissance in Southern Somalia." Nyame Akuma 22: 17.

_ 1988. "The Mainland Creeks of Southern Somalia: An Archaeological 
Appraisal." Proceedings of the Third International Congress of Somali Studies, vol. 4, 335-9. Rome: Pensiero Scientifico Editore.

Scheidegger, T. 2013. "Oxygen and Carbon Isotope Analysis of Human Tooth Enamel from Gogoshiis Qabe and Guli Waabayo Rock Shelters in Southern Somalia."

Unpublished honors thesis, Department of Anthropology, University of Florida.

Seland, E. H. 2014. "Archaeology of Trade in the Western Indian Ocean, 300

BC-AD 700." Journal of Archaeological Research 22: 367-402. doi:10.1007/

s10814-014-9075-7

Seton-Karr, H. W. 1896. "Discovery of Evidences of the Palaeolithic Stone Age in Somaliland (Tropical Africa)." Journal of the Anthropological Institute of Great Britain and Ireland 25, no. 4: 271-75.

Sinclair, P. J. J. 1990. "Pottery from the 1986 Rescue Excavations at the Shangani Mosque Site in Mogadishu." In Urban Origins in Eastern Africa: Proceedings of the 1989 Madagascar Workshop, edited by P. J. J. Sinclair and J. A. Rakotoarisoa, 123-28. Stockholm: Swedish Central Board of National Antiquities.

Smith, M. C., and H. T. Wright. 1988. "The Ceramics from Ras Hafun in Somalia: Notes on a Classical Maritime Site." Azania 23: 115-41 . 1990. "Notes on a Classical Maritime Site: The Ceramics of Ras Hafun, Somalia." In Urban Origins in Eastern Africa: Proceedings of the 1989 Madagascar Workshop, edited by P. J. J. Sinclair and J. A. Rakotoarisoa, 106-14. Stockholm: Swedish Central Board of National Antiquities.

Solodovnikov, V. G., ed. 1974. Scientific Notes of the Soviet-Somali Expedition. Moscow: Academy of Sciences, Institute of Africa.

Solomon, H. S. 2006. "Zooarchaeology in Southern Somalia: A Study of Prehistoric Hunter-Gatherers Subsistence from Guli Waabayo Rock Shelter." Unpublished thesis, University of Florida.

Torres, J. de, A. González-Ruibal, M. A. Franco, C. Martínez, K. A. Aideed, and A. M. Shabelle. 2017. "Bulhar: A Colonial Town in Somaliland. Report from the 2017 Excavations." Nyame Akuma 87: 55-61.

Torres, J. de, A. González-Ruibal, M. A. Franco, and A. J. Dualeh. Forthcoming. "Medieval Archaeology in Somaliland: The 2018 Field Season of the IncipitCSIC Project." Nyame Akuma 89.

Trimingham, J. S. 1952. Islam in Ethiopia. London: Oxford University Press.

Warsame, S. A., A. Nikiforov, and L. L. Galkin. 1974. "The Archaeological Sites of Northern Somalia." In Scientific Notes of the Soviet-Somali Expedition, edited by 
V. G. Solodovnikov, 314-31. Moscow: Academy of Sciences, Institute of Africa [original in Russian].

Wilson, T. H. 1992. "Settlement Patterns of the Coast of Southern Somalia and Kenya." In Proceedings of the First International Congress of Somali Studies, Mogadishu, edited by H. M. Adam and C. L. Geshekter, 74-105. Atlanta, GA: Scholars Press.

NOTES

The Incipit-CSIC project has been funded by the State Programme for Scientific Research of the Spanish Ministry of Economy and Competitiveness (HAR201348495-C2-1-P) between 2014 and 2017 and by the Palarq Foundation since 2017 to the present. The author's research is funded by the European Union Research and Innovation Framework Programme, Horizon 2020, through the Marie Curie Actions Individual Fellowships (Proposal 795442). The author would like to thank Alfredo González-Ruibal and Shane Marotta for their suggestions during the preparation of the manuscript, and especially Professor Lee Cassanelli for his interest and help in the final versions of the manuscript. All mistakes in the article remain my own. The article would also like to acknowledge the work of all those involved in the preservation of the historical and archaeological Somali heritage, Somali and foreigners alike.

1. https://medievallandscapes.wordpress.com.

2. https://www.sadamire.com, https://www.facebook.com/somaliheritage, http:// www.somaliheritage.org,@SomaliHeritage.

3. @Arch_Somaliland

4. http://somaliarchitecture.com/, @Somarchitecture.

\section{ABOUT THE AUTHOR}

Jorge de Torres Rodríguez is a Marie Curie Fellow at the Institute of Heritage Studies (Incipit) of the Spanish National Research Council (CSIC) with 14 years of experience in archaeological research in Morocco, Sudan, Somaliland, Mozambique and Ethiopia, with specialization in historical archaeology in the Horn of Africa. He is the co-director of the Incipit-CSIC 
project in Somaliland, the only archaeological project active in the region, and currently studies the relationships between nomads and urban dwellers in western Somaliland during the medieval period. 